\title{
Biotechnological preparation of sewage and livestock manure from livestock farms for the needs of horticulture
}

\author{
Anatoly Bondarenko ${ }^{1, *}$, Liudmila Kachanova ${ }^{2}$, Yuri Kolosov ${ }^{1}$, Agnessa Shakhmurzova ${ }^{3}$, and \\ Anatoly Bittirov ${ }^{3}$ \\ ${ }^{1}$ State Federal-Funded Educational Institution of Higher Professional Training "Don State Agrarian \\ University", Krivoshlykova 24, rural settlement Persianovskiy, 346493 Rostov region, Russia \\ ${ }^{2}$ State Federal-Funded Educational Institution of Higher Professional Training "Don State Technical \\ University", Gagarin Square 1, 344000 Rostov-on-Don, Russia \\ ${ }^{3}$ Kabardino-Balkarian State Agricultural University named after V.M. Kokov, Lenin Avenue, 1V, \\ 360030 Nalchik, Russia
}

\begin{abstract}
Ensuring food security of the state provides for obtaining high yields of agricultural crops and the development of livestock facilities. The aim of the investigation is to develop an accelerated biotechnological preparation of sewage and livestock manure from livestock farms for irrigation of pastures and fertilization of fields for forage crops. Closedloop systems for products output on pig farms and cattle farms using biotechnology for the preparation of livestock manure for irrigation of fields in the production of forage crops have been developed. The biotechnology of accelerated preparation of sewage and liquid livestock manure is based on the principles of their mechanical separation into fractions with the subsequent preparation of liquid concentrated organic fertilizers using nutraceuticals, which speed up the processes of their preparation in a much shorter time than using traditional technologies. A closed-loop system for products output on sheep and pig farms and cattle farms using biotechnology is proposed. The basis of biotechnology in the processing of solid livestock manure is the principle of accelerated components composting using nutraceuticals. The implementation of accelerated preparation system of sewage and livestock manure for irrigation of pastures and fertilization of fields for forage crops contributed to an increase in their yield up to $20.54 \%$. At the same time, the milk yield per forage cow increased by $8.47-14.20 \%$; average daily weight gain - by $13.30-47.73 \%$.
\end{abstract}

\section{Introduction}

To ensure the food security of the state, a well-coordinated work of the agro-industrial complex and its basic industries: horticulture and animal husbandry is required. In 2019, a record harvest of grain crops was gathered in the Russian Federation in the amount of 119

\footnotetext{
${ }^{*}$ Corresponding author: bondanmih@rambler.ru
} 
million tons, in 2020 - 122.0 million tons. In the Rostov region in 2020, 11 million tons of early grain crops and more than 1 million tons of corn for grain were harvested.

Obtaining high yields is accompanied by the removal of significant amounts of nutrients from the soil and, as a result, its depletion.

In recent years, the system of organic farming has been developing, which, along with obtaining ecologically clean products, is based on the principle of preserving the soil fertility of agricultural lands. More than 60 million tons of humus are mineralized in the arable soils of the Russian Federation annually, and about 27 million tons are replenished. To replenish it, it is required to use organic fertilizers, which have a positive effect on the balance of organic substance in the soil. Currently, there is a difficult situation with the provision of farmland with organic fertilizers.

Over the past 30 years, the output of livestock manure in the Rostov region has decreased from 32 million tons to 3.2-3.5 million tons, which is clearly not enough to restore soil resources. This problem can be solved by mobilizing all resources of organic raw materials, first of all, livestock manure sewage and livestock manure from animal enterprises.

For the effective management of animal husbandry, it is necessary to have its own forage base. For this purpose, restoration of pastures and fields for forage crops is required on the basis of the development and implementation of accelerated biotechnology for the preparation of sewage and livestock manure as organic fertilizers. In the Rostov region, pastures occupy 2,497 thousand hectares $(24.8 \%$ of the total area). Hay meadow occupy 90.2 thousand hectares $(0.9 \%$ of the total area) [1].

In this regard, the problem of the effective functioning of animal enterprises with a closed technological cycle on their own forage base is relevant, it is of scientific and practical interest.

The aim of the investigation is to develop an accelerated biotechnological preparation of sewage and livestock manure from livestock farms for irrigation of pastures and fertilization of fields for forage crops.

\section{Materials and Methods}

The analysis and synthesis of livestock manure preparation systems for use is based on a systematic approach to the study of the issues under consideration and is determined by the internal and external relations of the animal husbandry and horticulture sectors. System analysis is a process of use, at which the parameters of the system operation are determined from the known parameters of the system and the environment.

System synthesis is a process of its investigation, at which, according to the required indicators of the system operation and the existing restrictions on resources in known environmental conditions, it is necessary to determine the parameters of the system (promising biotechnologies for the preparation of sewage and livestock manure). Practical methods of system investigation are based on the analysis, synthesis and observance of their unity at all stages of research [2-4].

On the basis of the above mentioned, systems of a closed production cycle have been developed on pig farms, cattle farms and sheep farms. The particular importance for the steady operation of animal enterprises are the operations of feeding, removing livestock manure, its accumulating, storing and processing into high-quality organic fertilizers [5].

Depending on the technology of keeping animals on farms and complexes, they produce solid (bedding) manure (LM), semi-liquid manure (SLM) and liquid manure (LM). Fresh, all these types of livestock manure have a large amount of pathogenic microflora and pose a danger to flora and fauna in places of their accumulation and storage.

Livestock manure produced at animal and poultry enterprises in the legislative 
framework of the Russian Federation is defined as waste of IV and V hazard classes [6]. According to the Russian Ministry of Natural Resources livestock manure, dung and other organic substances and materials formed in animal husbandry as a result of keeping farm animals and which are waste products of the latter ones, after disinfection in accordance with sanitary rules, as well as organic fertilizers produced on their basis, can be sold as a product, complying with the following conditions:

- in the presence of statutory, design, technological and other documents, which make it possible to classify livestock manure, dung, other organic substances formed at enterprises as a result of economic activities, to products;

- in the presence of developed and approved technical conditions for fertilizers based on livestock manure, dung, other organic substances, which take into account state and industrial standards, sanitary and hygienic standards and regulations, environmental requirements, as well as in the presence of process procedure for livestock manure, dung, organic substances and materials;

- when reflecting in the economic, accounting records of the enterprise, operations with the specified livestock manure, dung, other organic substances and materials as operations with products.

Therefore, if the above requirements are met, livestock manure produced in animal enterprises can be considered a product. Implementation of the requirements for transferring waste (livestock manure) into a product (organic fertilizer) requires improvement of the technical means for recycling organic waste $[7,8]$.

Particular attention in the production of livestock products abroad is given to reducing the emission of ammonia and other gases into the atmosphere. In the Netherlands, pollution reductions are being tested on small pilot farms [9]. Similar experiments are being carried out in Denmark, where supplementary systems for the use of protein for cattle feed and their effects on ammonia production are further investigated [10]. Much attention has been paid to the research of multi-stage cleaners to reduce emissions of harmful substances on pig farms [11]. Research is under way in European countries on groups of microorganisms that reduce ammonia emissions at poultry farms [12]. The most effective direction is the recycling of organic livestock and poultry waste into organic fertilizers both independently and in conjunction with organic crop waste (straw, non-grain portion of other agricultural crops) [5].

Scientists in the 70 s and 80 s of the twentieth century actively developed technologies for processing all types of livestock manure into organic fertilizers and technical means for their implementation. In the case of large animal enterprises producing liquid manure and dung, mechanical separation technologies have been developed, followed by solid and liquid organic fertilizers. In the processing of semi-liquid manure, the preference was given to the technologies of compost production using various moisture absorbers (straw, peat, etc.). Bedding manure, as a rule, was processed by traditional technology: accumulation, drilling, periodic drilling, applying in the fields (Figure 1) [13].

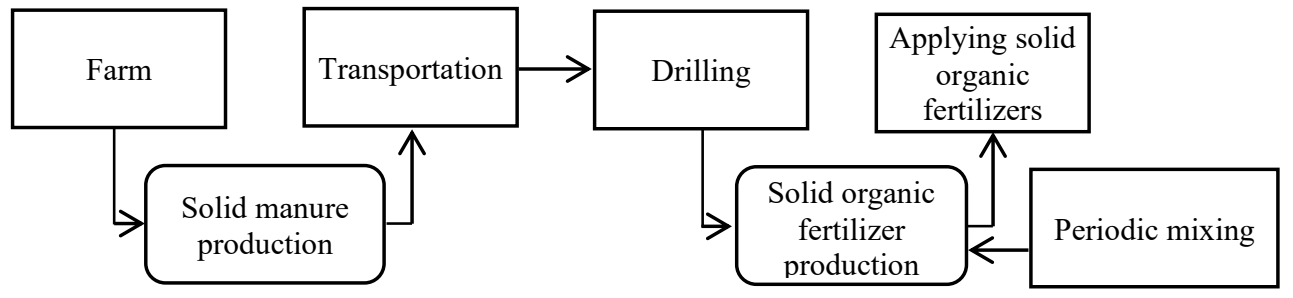

Fig. 1. Solid manure processing scheme

Recycling semi-liquid manure $(\mathrm{W}=86-92 \%)$ provides the operation of its transporting, 
accumulation, compost production using a moisture absorber - straw, or applying in the field (after soaking in the storage sediments for up to 12 months) as a semi-liquid organic fertilizer (SLOF) (Fig. 2).

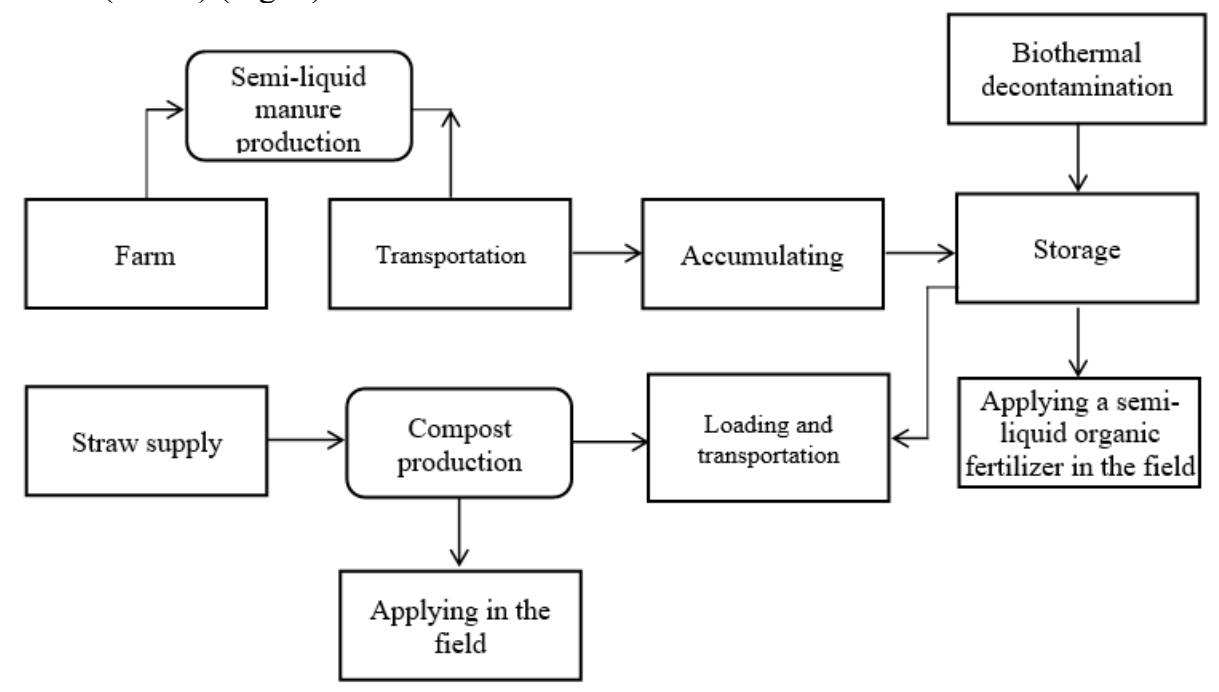

Fig. 2. Solid manure processing technology scheme

Liquid manure produced at animal enterprises is processed under two options.

Option 1. Production of liquid organic fertilizers (LOF) by soaking up to 12 months in storage ponds.

Option 2. Mechanical division of liquid manure into solid (TF) and liquid (FF) fractions with separate processing of them into solid (SOF) and liquid (LOF) organic fertilizers (Figure 3).

Under option 1, liquid manure accumulates in the farm sediment and is pumped by pipelines into two-section storage ponds. Natural decontamination occurs within 12 months, after which liquid organic fertilizer is applied in the fields by means of specialized machines for fertilizing feed and grain crops. The drawbacks of this technology are: a high risk of environmental pollution, so, dung storage facilities often do not have bottom and side wall insulating coating; significant costs of mixing and loading of the LOF; high doses of application - from 400 to $700^{3} / \mathrm{ha}$. 


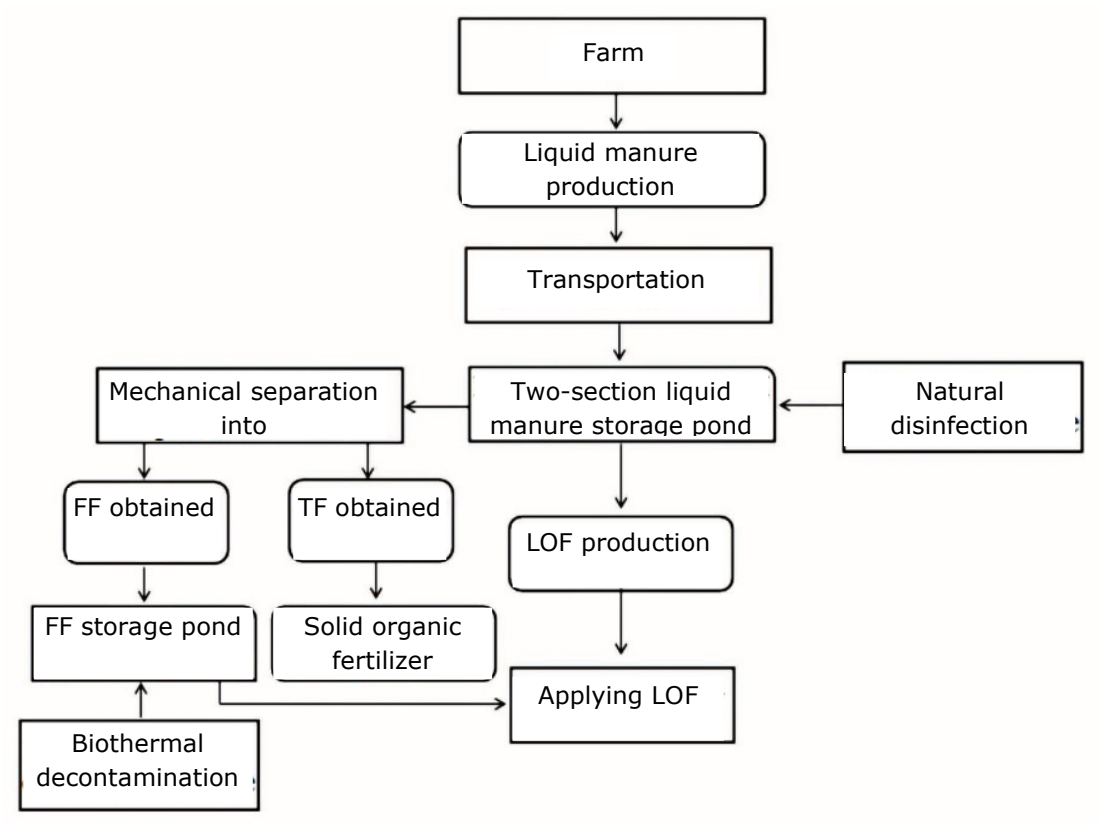

Fig. 3. Liquid manure processing technology scheme

Option 2 is the most acceptable, which involves separating liquid manure into solid and liquid fractions and separating them from integration into solid and liquid organic fertilizers.

The analysis of the liquid manure separation system for the fraction showed the following. Developed earlier systems of machines for processing liquid pig manure at large pig farms are not effective at small farms, because they have high productivity, relatively large dimensions, require additional labor costs, etc.

For small and medium-sized farms, it is appropriate to develop technical devices that are organically related to the main production or are a natural extension of it. In any case, it should be simple, compact, reliable in operation technical means, designed to handle small daily volumes of manure.

\section{Results and Discussion}

The analysis showed that existing systems for preparing sewage for irrigation of pastures and livestock manure for fertilizing fields did not satisfy agricultural producers for lack of effective technologies and technical means to implement them.

The essence of the closed cycle of the farm operation lies in the fact that the cattle population is provided with vital options - feed and watering, produced on its own base, which is ensured by waste-free production that guarantees environmental safety and economic stability of the enterprise.

Figure 4 shows that the amount of produced pig farm (PPF) depends on the cattle population. The main product is meat, with effectively technological processes for the steady production associated, first of all, with the creation of a microclimate, feeding, watering and cleaning livestock manure.

The microclimate systems of animals and their watering are sufficiently performed and are selected depending on the number of cattle animals and the volume of premises where they are located $[8,9,14]$. 


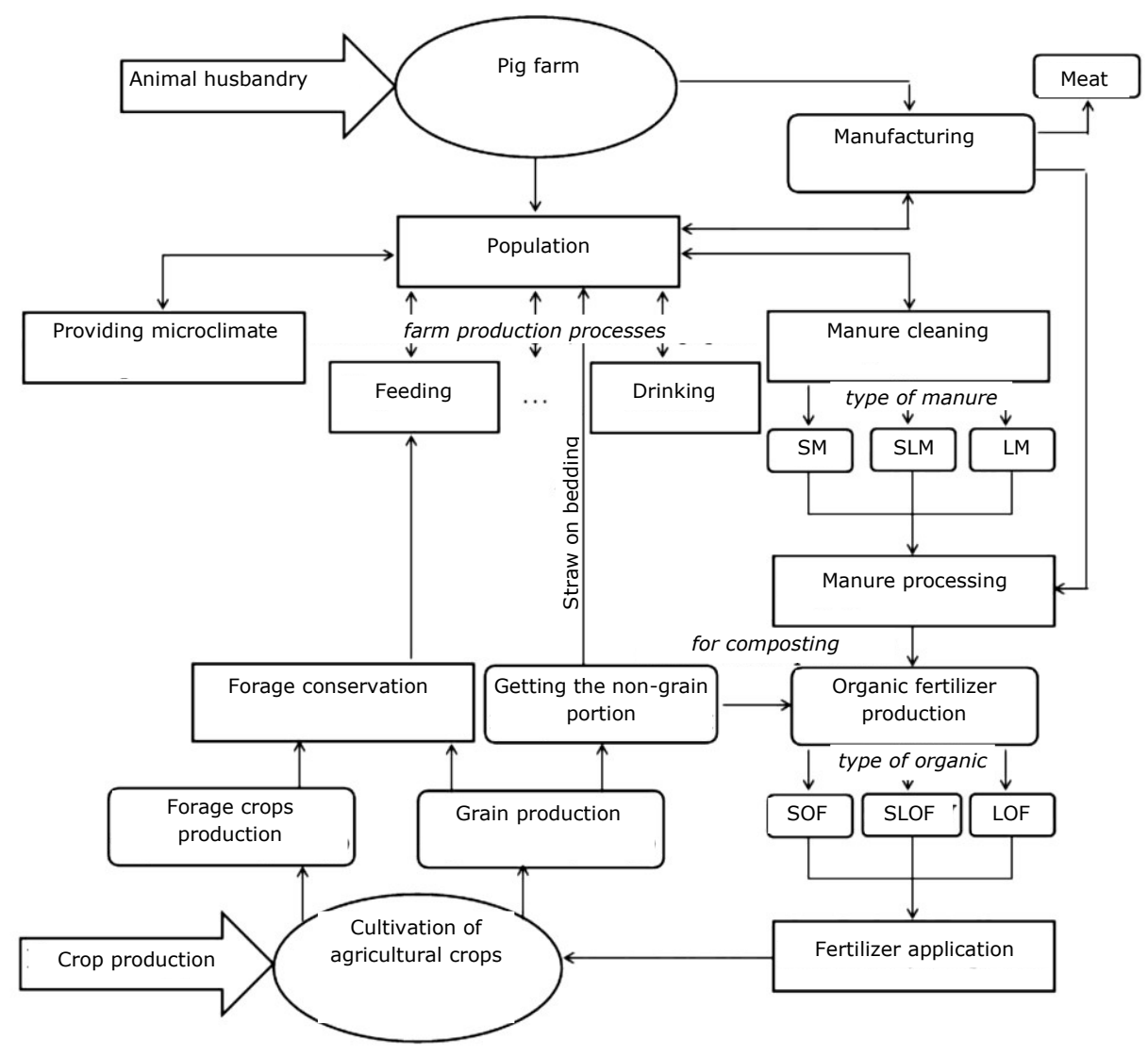

Fig. 4. Closed-loop systems for products output on produced pig farms using biotechnology for the preparation of livestock manure for irrigation of fields in the production of forage crops

An important factor influencing the profitability of livestock production is the availability of a feed base. The use of its own feed base in the closed cycle of livestock production allows not only to increase profitability, but also to improve the ecological situation at the places of livestock enterprise and to preserve the soil fertility of agricultural land.

Figures 5 and 6 show the closed cycle systems for the production of cattle farms and sheep farms. The basic principles of these systems are similar to the system represented in Figure 4.

In the closed cycle system of the animal enterprise, an important task is to develop accelerated biotechnology of sewage and livestock manure preparation as organic fertilizers for the cultivation and production of forage crops. This is especially relevant for the processing of liquid manure and dung sewage. 


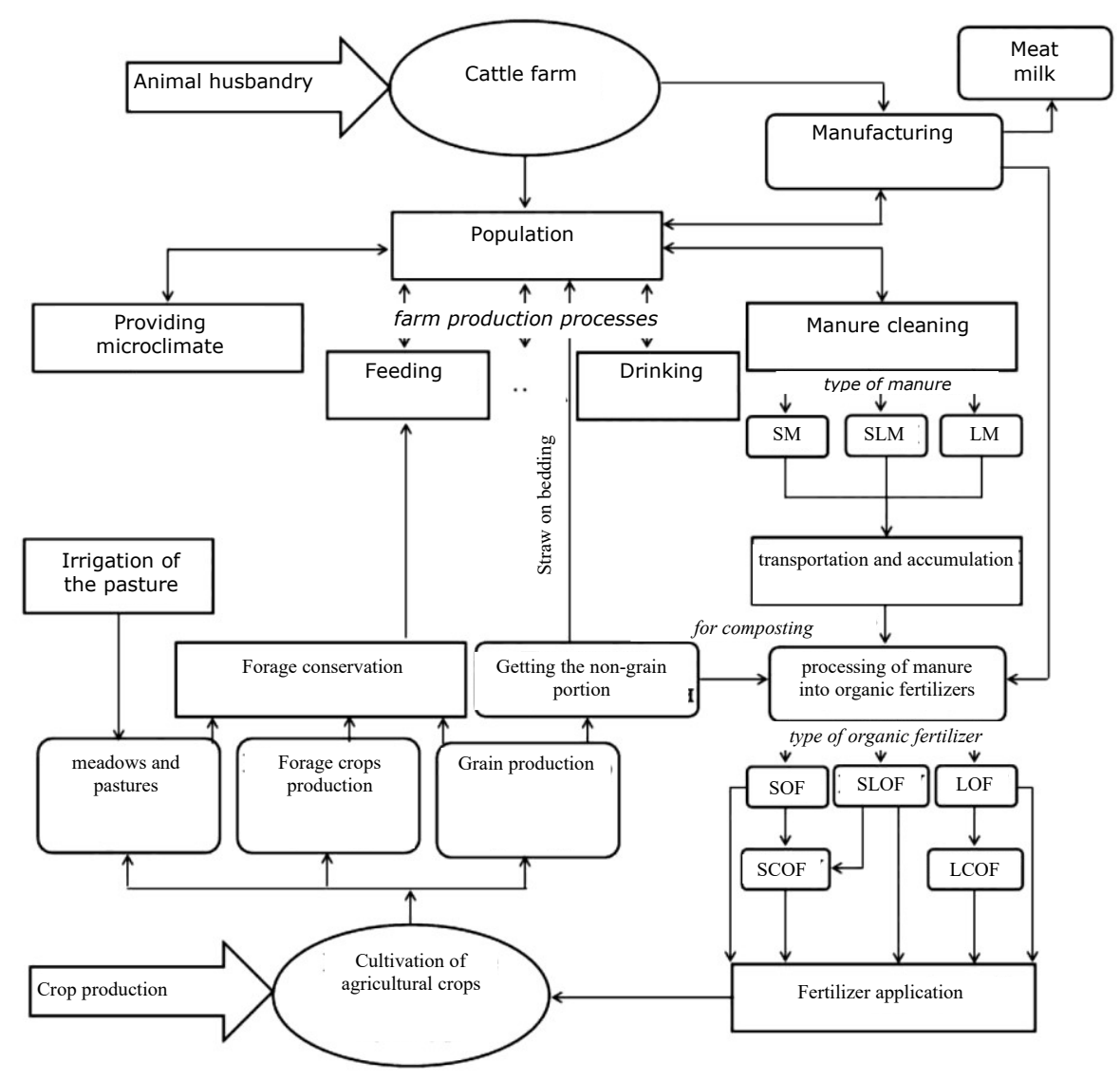

Fig. 5. A closed-cycle production system for cattle farms using sewage and livestock manure preparation biotechnology for irrigation and pasture fertilizing

Research on the development and implementation of agricultural waste management biotechnology is performed in the Russian Federation and abroad.

The solid, semi-liquid and liquid manure produced on the farms is to be recycled (Fig. $4,5)$.

Technology of manure processing through dehydration and further sterilization, according to some experts, is very energy-intensive. Thermal treatment of liquid or solid fraction at high temperatures causes loss of food items for plants. In addition, the main requirements for technologies of processing livestock waste and obtaining organic fertilizers are the preservation of their biological activity and the maximum content of nitrogen, phosphorus and other elements.

One possible way to dispose of livestock waste is biological processing using micro and macroorganisms, allowing the rapid and efficient processing of a significant amount of livestock manure and dung.

A promising way of biologically disposing of livestock waste is to cultivate microorganisms. For the fermentation of livestock manure mainly used filamentous fungi (solid-phase cultivation), and bacteria, yeast and fungi are deeply cultivated on dung sewage. The cultivation of bacterial crops on waste from livestock complexes has not been widespread due to the limited use of bacteria for forage. 


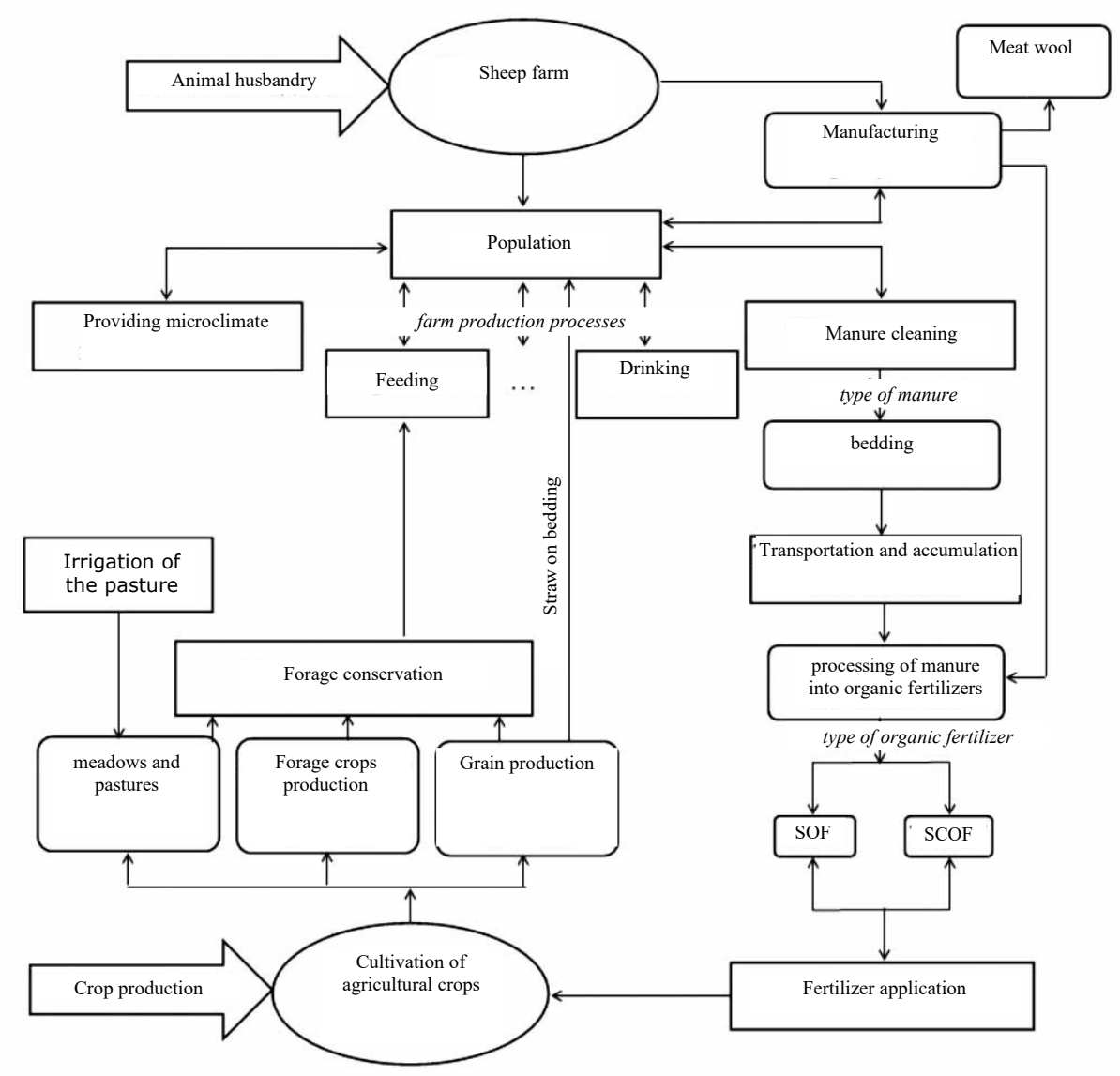

Fig. 6. A closed-cycle production system for produced sheep farms using sewage and livestock manure preparation biotechnology for irrigation and pasture fertilizing

There is a wide range of microorganisms capable of consuming secondary agricultural and processing products with microbial biomass. The most promising are fast-growing microorganisms that can absorb unhydrized agricultural waste. Filamentous fungi and yeast comply most with these requirements. It is known that concentrated sewage is essentially a ready breeding ground for these microorganisms, as they contain all the necessary components, including vitamins and trace elements [15-20]. In addition, the rational use of livestock sewage allows to obtain an additional yield, in monetary terms estimated equivalent to the use of 650,000 tons of nitrogen, 300,000 tons of phosphorus and 600,000 tons of potash fertilizers throughout the Russian Federation.

In general, the best way to dispose of waste for economic and environmental reasons is to use it as a secondary raw material. The above-mentioned methods of waste bioconversion can produce, sometimes unexpectedly, very significant results with beneficial implications for the development of biotechnology and energy. Unfortunately, most of them are implemented very poorly.

Scientists of the Don Agricultural University developed biotechnology of accelerated processing of different consistency organic waste using nutraceuticals. Adding up to $5 \%$ of nutraceuticals to the recyclable volume of organic waste (livestock manure) makes it possible to get in a short time (from 7 to 12 days) high-quality concentrated organic fertilizers: solid (SCOF), liquid (LCOF) (figure 5, 6), which are applied in the field with 
doses of up to $4 \mathrm{t} / \mathrm{ha}$. This biotechnology allows for the quality preparation of sewage for irrigation of pastures and livestock manure for fertilizing fields both in the production of feed and for other crop production needs.

The system of high-quality irrigation of pastures and fertilization of fields for feed crops has been tested in a number of agricultural organizations in the Rostov region. The system is used in the production activities of the Agricultural Production Cooperative-collective farm named after S.G. Shaumian, Miasnikov district, Agricultural Production Cooperative (collective farm) "Rodina" of the Matveyev-Kurgan district, CJSC "Kolkhoz Sovietinsky" in Neklinovsky district, Rostov region.

For example, in the Agricultural Production Cooperative-collective farm named after S.G. Shaumian, Miasnikov district was one of the first in the region to test the high-quality system of pastures irrigation and fertilizing the fields for feed crops. The production activities analysis of the Agricultural Production Cooperative-collective farm named after S.G. Shaumian over a 5-year period revealed an increase in the main performance indicators of the horticulture and animal husbandry industries. Yields of forage crops increased by $180 \mathrm{c} /$ ha, gross milk production increased by 1684 tons, yields per 1 forage cow increased by $771 \mathrm{~kg}$, the average daily weight gain increased by 251 grams. In general, sales of products for the period under review increased by 358 million rubles, net profit increased by 107.8 million rubles. The profitability of the sold products reached $24 \%$ in 2019 , which is 5 percentage points higher than in 2013. The enterprise's profitability in 2019 was $81 \%$, which is 48 percentage points higher than in 2013 .

\section{Conclusions}

Based on the production investigations and financial activities of enterprises they revealed: the introduction of a high-quality system of pastures irrigation and fertilizing fields for forage crops had a positive impact on the results of production activities. In the Agricultural Production Cooperative (collective farm) the yield of forage crops, yields and weights of animals increased. Receipts from sales of enterprise agricultural products is growing steadily. Net profit varies somewhat, which is due to the increase in production and sales costs. The net profit of organizations also tends to increase.

Enterprises implementing a system of pastures high-quality irrigation and fertilizing fields for forage crops use the latest scientifically sound technologies, which contributes to the efficiency of the process and labor discipline. It is worth noting that the use of pastures high-quality irrigation system and fertilizing fields for forage crops contributes to the social orientation of enterprises, as new jobs are being created and the environmental situation in the agricultural sites is improving.

\section{References}

1. V. N. Vasilenko, Zonal farming systems of the Rostov region for 2013-2020 (2013)

2. E. N. Krylatykh, V. Z. Mazloyev, V. V. Rau, A. S. Strokov, National Economy: ensuring Food Security in the face of Integration and Globalization (2015)

3. E. I. Lipkovich, APK: Economics and Governance, 5, 12-20 (2014)

4. A. M. Gataulin, Russian Agriculture Economy, 1, 87-90 (2009)

5. A. M. Bondarenko, L. S. Kachanova, Technologies and Techniques for the Production and Application of Organic Fertilizers (2016) 
6. A. Yu. Briukhanov, D. A. Maximov and others, Recommendations for organizing and conducting industrial environmental control of the processing and use of livestock manure (dung) (2012)

7. A. I. Bogachev, M. G. Poluhina, Agricultural and Energy Supply, 3(7) (2015)

8. I. Yu. Svinariov, I. N. Mikhailova, KubGAU Science Journal, 91(07), 1147-1156 (2013)

9. J. Oenema, and ethers, NJAS - Wageningen Journal of Life Sciences, 58, 39-48 (2011)

10. Van Duinkerken, G.V.C., Journal of Dairy Science, 149, 351-367 (2011)

11. Zhao Y., Effectiveness of multi-stage scrubbers in reducing emissions of air pollutants from pig houses Transactions of the ASABE, 54, 285-293 (2011)

12. Aubert C., Comference paper for les 9emes Joumees de la Recherche Avicole, Tours, France, 116-120 (2011)

13. Yu. E. Domashenko, S.M. Vasilyev, Polythematic network electronic scientific journal of the Kuban State Agrarian University, 106(02), 568-579 (2015)

14. I. V. Atanov, A. M. Bondarenko, D. I. Gritsay, Reconstruction and technical reequipment of farms and cattle complexes: a study guide (2017)

15. R. G. Gosmanov, A. H. Volkov, A. K. Galiullin, A. I. Ibragimova, Sanitary Microbiology (2010)

16. K.-S. Chen, Environmental Technology, 33(4), 487-495 (2012)

17. F. Bichai, Water Research, 46(18), 6040-6050 (2012)

18. Alley, M. International Fertilizer Industry Association, 61 (2009)

19. H.-W. Gripentrog, K. Persson, Managing variability - tools, methods and software: Third European conference on precision agriculture, 2, 671-676 (2001)

20. I. Kristaponyte, Agronomy Research, Estonia, 3(1), $45-54$ (2005)

21. T. I. Gulyaeva, V. I. Savkin, E. Y. Kalinicheva, O. V. Sidorenko, E. V. Burayeva, Journal of Environmental Management and Tourism, 9(8), 1789-1798 (2018)

22. V. V. Prokhorova, E. N. Klochko, O. N. Kolomyts, A. V. Gladilin, International review of management and marketing, 6, 159-164 (2016) 